\title{
Differences in Virulence and Genomic Features of Strains of 'Candidatus Phytoplasma mali', the Apple Proliferation Agent
}

\author{
Erich Seemüller and Bernd Schneider
}

Federal Biological Research Centre for Agriculture and Forestry, Institute for Plant Protection in Fruit Crops, D-69221 Dossenheim, Germany.

Accepted for publication 28 March 2007.

\begin{abstract}
Seemüller, E., and Schneider, B. 2007. Differences in virulence and genomic features of strains of 'Candidatus Phytoplasma mali', the apple proliferation agent. Phytopathology 97:964-970.

Root and shoot samples from 24 symptomatic or nonsymptomatic apple trees infected with 'Candidatus Phytoplasma mali' were collected at different locations in Germany and France and used to inoculate rootstock M11 top grafted with cv. Golden Delicious. Inoculated trees were monitored over a 12-year period for apple proliferation (AP) symptoms and categorized as not or slightly, moderately, or severely affected. Based on symptomatology, the phytoplasma strains were defined as being avirulent to mildly, moderately, or highly virulent. Determination of phytoplasma titers by quantitative polymerase chain reaction (PCR) with DNA from roots revealed similar phytoplasma concentrations in all virulence groups. Molecular characterization of the strains by differential

PCR amplification with five sets of primers resulted in 13 profiles. Six strains that were maintained in periwinkle and tobacco were molecularly characterized in more detail. The genome sizes of these strains as determined by pulsed-field gel electrophoresis using yeast chromosomes as size references ranged between 640 and $680 \mathrm{~kb}$. Cleavage of the chromosome with the rare cutting restriction enzymes ApaI, BamHI, BssHII, $M l u \mathrm{I}$, and $S m a \mathrm{I}$ resulted in macro fragment patterns distinctly different in all strains. Similar results were obtained by Southern blot hybridization with three probes derived from strain AT. Differential PCR amplification at an annealing temperature of $52^{\circ} \mathrm{C}$ using eight primer pairs derived from strain AT revealed heterogeneity of target sequences among all strains. Based on these results, there is considerable variability in virulence and genomic traits in ' $\mathrm{Ca}$. P. mali'. However, correlations between molecular markers and virulence or phytoplasma titer could not be identified.
\end{abstract}

Apple proliferation (AP) is caused by the unculturable, wallless bacterium 'Candidatus Phytoplasma mali' of the class Mollicutes. The disease is one of the most important phytoplasmal diseases in Europe occurring in several major apple-growing regions, where it causes considerable economic losses. AP induces a range of symptoms that are either nonspecific, such as foliar reddening and yellowing, growth suppression, and undersized fruit, or specific, such as witches'-brooms, rosettes, and enlarged stipules. The disease is vectored mainly by the psyllids Cacopsylla picta and $C$. melanoneura $(11,35)$. Surveys have shown that the percentage of infected trees may be very high. In most areas of southwestern Germany, all or nearly all trees older than 8 years that were grown in low-intensity orchards proved to be infected (28). High infection rates also were observed in commercial orchards (8).

Due to its economic importance, ' $\mathrm{Ca}$. P. mali' is one of the most intensively studied phytoplasmas. Molecular methods to characterize isolates of the AP agent showed that, at the level of $16 \mathrm{~S}$ rDNA and $16 \mathrm{~S}-23 \mathrm{~S}$ rDNA spacer sequences, ' $\mathrm{Ca}$. P. mali' is a very homogenous species throughout Europe (32). However, comparisons based on an immunodominant membrane protein gene, other genes, randomly cloned DNA fragments, and genome sizes revealed genetic differences between isolates $(4,12,13)$. The same is true for immunological analyses using monoclonal antibodies and polyclonal antisera (32). Subtypes of ' $\mathrm{Ca}$. P. mali' have been delineated by restriction fragment length polymorphism (RFLP) analyses of polymerase chain reaction (PCR)

Corresponding author: E. Seemüller; E-mail address: e.seemueller@bba.de

doi:10.1094/PHYTO-97-8-0964

This article is in the public domain and not copyrightable. It may be freely reprinted with customary crediting of the source. The American Phytopathological Society, 2007. fragments and Southern blot hybridization and designated as AP, AT or AT-1, and AT-2 (12,13).

Phytoplasma concentrations in infected plants differ greatly. High-titer hosts are Catharanthus roseus (periwinkle) and herbaceous plants such as lettuce and celery $(3,10)$. Low numbers often are observed in woody hosts such as decline-diseased Populus spp. in which phytoplasma concentrations are often below the detection level of microscopic methods $(5,29)$. In the genus Malus, both low- and high-titer hosts occur. Previous comparisons using fluorescence microscopy indicated that phytoplasma concentrations in AP-susceptible, Malus $\times$ domestica-based rootstocks are much higher than in AP-resistant apomictic rootstocks that derived from Malus sieboldii (30). Thus, it was conceivable that disease severity is linked to phytoplasma concentration and that mild strains reach lower titers than severe strains due to their lower pathogenic fitness.

There is sparse information about variation in aggressiveness of phytoplasma strains within a given taxon. Such differences are known from the ash yellows pathogen ' $\mathrm{Ca}$. P. fraxini', the alder yellows agent, and the close ' $\mathrm{Ca}$. P. mali' relative ' $\mathrm{Ca}$. P. prunorum' $(6,14,33,34)$. The earliest information on differences in virulence within ' $\mathrm{Ca}$. P. mali, stems from Kunze, (16) who grafted roots from different sources of affected trees to young recipient trees and observed the inoculated trees for symptom development over several years. The recipient trees responded to infection as expected from disease severity of the donor trees. Phytoplasmas from severely affected trees caused severe symptoms in the inoculated trees, whereas the pathogens from lessaffected trees induced milder symptoms.

The objective of our work was to investigate the virulence of AP phytoplasma strains in more detail. Unlike Kunze (16), who used only inoculum from symptomatic trees, we included sources from nonsymptomatic trees because there is an indication that 
vigorous, nonsymptomatic apple trees often are infected by ' $\mathrm{Ca}$. P. mali' in the roots (7; E. Seemüller, unpublished data). Furthermore, to examine greater genetic diversity, we compared considerably more phytoplasma strains than Kunze (16). The possible relationship between virulence and phytoplasma concentration was investigated by determining the titer of the pathogen in the root phloem of infected trees using quantitative real-time PCR. Root phloem is a better source than stem phloem for this purpose because phytoplasmas are eliminated in the top of the trees during the dormant season. The pathogen persists in the roots from where it may recolonize the stem in the spring $(27,31)$. To identify molecular markers that may be linked to virulence, various genetic tools were employed, including chromosome size determination, RFLP analysis using rarely and frequently cutting enzymes, and differential PCR amplification.

\section{MATERIALS AND METHODS}

Plant material. In summer and fall 1993, root or shoot samples from 24 symptomatic and nonsymptomatic apple trees mostly grown in low-intensity orchards were collected in the states Baden-Württemberg, Rheinland-Pfalz, and Hessen of Germany and in Burgundy, France (Table 1). Root or shoot scions were grafted onto healthy rootstock M 11 that then was top grafted with cv. Golden Delicious. Four rootstocks were top grafted with scions from a healthy tree as controls. The inoculated trees were kept in pots for 1 year and then transferred to the field for further observation. Plant protection measures were similar to those in commercial orchards. AP phytoplasma strains 1/93, 5/93, and $12 / 93$ were transmitted from apple to periwinkle and from periwinkle to tobacco (Nicotiana occidentalis and N. tabaccum $\mathrm{cv}$.
Samsun) via dodder (Cuscuta europaea) bridges. Italian strain AT-2 was more recently transmitted to periwinkle and, therefore, was not included in all experiments. Strains AT and AP15 that were previously transmitted to periwinkle $(8,23)$ were transmitted to tobacco in this work. The strains were maintained by periodic grafting in the experimental hosts in an insect-proof greenhouse.

Symptom evaluation and disease rating. Over a 12-year period, foliar symptoms (reddening, yellowing, enlarged stipules, witches'-brooms, and rosettes), terminal growth, and fruit size of the trees were recorded annually in the late summer or early fall using a rating system from 0 (no symptoms) to 3 (severe symptoms). Symptom rating categories were slight reddening or mild yellowing $=0.5$; enlarged stipules and severe reddening or yellowing $=1$; reduced vigor $=2$; and witches'-brooms, undersized fruit, and severe stunting $=3$. Slight reddening and yellowing were considered as nonspecific symptoms when mild specific symptoms such as enlarged stipules were absent. At the end of the observation period, the highest annual rating values were added so that accumulated disease indices were obtained. The trunk girth was measured $40 \mathrm{~cm}$ above the ground at the end of the trial.

DNA extraction. DNA from tobacco and periwinkle was extracted by a phytoplasma enrichment procedure as previously described (1). For PCR amplification of DNA from infected apple trees, phloem was prepared from three randomly collected roots of each tree as described (2) and DNA was extracted according to Doyle and Doyle (9). The extraction was performed under standardized conditions so that the amount of DNA obtained from each preparation was comparable. The nucleic acid pellets were resuspended in $500 \mu \mathrm{l}$ of sterile distilled water.

Differential PCR amplification. DNA extracted from either AP phytoplasma-infected apple phloem, periwinkle, or tobacco

TABLE 1. Virulence of 'Candidatus Phytoplasma mali' strains in apple trees and phytoplasma concentrations in roots of inoculated trees

\begin{tabular}{|c|c|c|c|c|c|}
\hline \multirow[b]{2}{*}{ Strain no. } & \multicolumn{2}{|c|}{ Source tree } & \multicolumn{3}{|c|}{ Recipient tree $^{\mathrm{a}}$} \\
\hline & Geographic origin & Symptom $^{\mathrm{b}}$ & $\mathrm{DI}^{\mathrm{c}}$ & Trunk $(\mathrm{cm})$ & Cells \\
\hline \multicolumn{6}{|c|}{ Noninoculated trees as controls } \\
\hline$\ldots$ & $\ldots$ & $\mathrm{H}$ & $1.0 \mathrm{~N}$ & 40 & 0 \\
\hline$\ldots$ & $\ldots$ & $\mathrm{H}$ & 0 & 34 & 0 \\
\hline$\ldots$ & $\ldots$ & $\mathrm{H}$ & 0 & 36 & 0 \\
\hline \multicolumn{6}{|c|}{ Avirulent and mild strains } \\
\hline $5 / 93$ & Schwäb. Gmünd & WB & $2.5 \mathrm{~N}$ & 38.5 & $5.0 \times 10^{8}$ \\
\hline $1 / 93$ & Burgundy, France & ES & $5.0 \mathrm{~S}$ & 40 & $3.2 \times 10^{8}$ \\
\hline $15 / 93$ & Heidelberg & ES & $7.5 \mathrm{~S}$ & 28 & $4.3 \times 10^{8}$ \\
\hline $13 / 93$ & Ludwigshafen & WB & $8.0 \mathrm{~S}$ & 33.5 & $5.4 \times 10^{9}$ \\
\hline $4 / 93$ & Stuttgart & NS & $9.5 \mathrm{~S}$ & 36.6 & $2.5 \times 10^{8}$ \\
\hline \multicolumn{6}{|c|}{ Moderately virulent strains } \\
\hline $24 / 93$ & Kassel & $\mathrm{U}$ & $12.5 \mathrm{~S}$ & 29 & $1.8 \times 10^{7}$ \\
\hline $10 / 93$ & Heidelberg & ES & $20.5 \mathrm{~S}$ & 24 & $1.2 \times 10^{9}$ \\
\hline $25 / 93$ & Kassel & $\mathrm{U}$ & $21.0 \mathrm{~S}$ & 24 & $1.6 \times 10^{7}$ \\
\hline \multicolumn{6}{|c|}{ Severe strains } \\
\hline $14 / 93$ & Dossenheim & WB & $24.0 \mathrm{~S}$ & 13.5 & $2.3 \times 10^{9}$ \\
\hline $20 / 93$ & Heidelberg & WB & $26.0 \mathrm{~S}$ & 7 & $2.6 \times 10^{8}$ \\
\hline $6 / 93$ & Dossenheim & NS & $27.5 \mathrm{~S}$ & 13 & $3.2 \times 10^{8}$ \\
\hline $9 / 93$ & Heidelberg & LV & $28.5 \mathrm{~S}$ & 14 & $8.6 \times 10^{8}$ \\
\hline $12 / 93$ & Dossenheim & LV & $28.5 \mathrm{~S}$ & 15 & $1.2 \times 10^{9}$ \\
\hline $3 / 93$ & Stuttgart & LV & $28.5 \mathrm{~S}$ & 7 & $1.3 \times 10^{9}$ \\
\hline $18 / 93$ & Heidelberg & WB & $32.0 \mathrm{~S}$ & 7.5 & $4.5 \times 10^{9}$ \\
\hline $19 / 93$ & Heidelberg & WB & $30.0 \mathrm{~S}$ & 8 & $3.4 \times 10^{7}$ \\
\hline $8 / 93$ & Dossenheim & WB & $33.0 \mathrm{~S}$ & 7.5 & $6.6 \times 10^{9}$ \\
\hline
\end{tabular}

${ }^{a} \mathrm{DI}=$ accumulated disease index, Trunk = trunk girth, and Cells = phytoplasma cells per gram of phloem tissue.

${ }^{b}$ At time of sampling. $\mathrm{H}$, healthy; WB, witches' broom; ES, enlarged stipules; U, unknown, root samples randomly collected in the dormant season; NS, no symptoms; and LV, low vigor.

c Annual symptom ratings accumulated over 12 years. $\mathrm{N}$ and $\mathrm{S}=$ nonspecific and specific symptoms, respectively. 
was used as template for differential PCR amplification. Primers were designed from various locations distributed over the chromosome of strain AT (M. Kube, B. Schneider, and E. Seemüller, unpublished data). The following eight primer combinations were used: f318A/r318B, 3-1/4-1, 26/27, 33/34, 41/42, 82/83, 100/103, and $216 / 220$ (Tab. 2). Amplification of DNA was performed in $25-\mu$ reactions containing $5 \mathrm{pmol}$ of each primer, $0.1 \mathrm{mM}$ each dNTP, $0.6 \mathrm{U}$ of heat-stable polymerase (Invitrogen), and $1 \times$ polymerase buffer. The reaction was cycled 35 times in a thermocycler (Stratagene) with the following parameters: $95^{\circ} \mathrm{C}$ for $1 \mathrm{~min}, 52^{\circ} \mathrm{C}$ $\left(55^{\circ} \mathrm{C}\right.$ for primers $\left.\mathrm{f} 318 \mathrm{~A} / \mathrm{r} 318 \mathrm{~B}\right)$ for $1 \mathrm{~min}$, and $70^{\circ} \mathrm{C}$ for 1 to 2.5 min according to the length of the fragment.

Southern blot hybridization. Primer pairs 3-1/3-2, 82/83, and 200/201 (Table 1) that were designed as described above were used to amplify PCR probes from strain AT DNA as template. Labeling was performed with the digoxigenin (DIG) PCR labeling kit (Roche) according to the specification of the supplier, except that the labeling mix was reduced to $1 / 12$ th of the specified amount and complemented with the unlabeled nucleotide mix due to the high AT content of the phytoplasma DNA. The PCR conditions were as described above. Incorporation of DIG was verified by comparing the mobility of labeled and unlabeled DNA by gel electrophoresis.

For Southern blotting, 10 to $15 \mu \mathrm{g}$ of DNA from plants infected with the five greenhouse-maintained AP phytoplasma strains were digested with 5 to $10 \mathrm{U}$ of restriction enzyme overnight according to the instructions of the manufacturer. Restricted phytoplasma DNA was electrophoresed overnight and blotted onto nylon membrane according to standard procedures (26). The membranes of three different digests were hybridized with a mixture of the three DIG-labeled probes and the signals detected by the chemiluminescence procedure recommended by the supplier of the labeling kit (Roche).

Quantitative PCR. Quantitative PCR was performed with the Bio-Rad iCycler IQ to estimate the AP phytoplasma concentrations in root phloem of infected trees. The amplification was performed in $50-\mu \mathrm{l}$ reactions containing 25 pmol of each primer (fAT/rATRT), 2 pmol of Taqman probe (Table 1) with a reporter fluorescence dye $(\mathrm{FAM})$ at the $5^{\prime}$ end and a quencher dye (TAMRA) at the $3^{\prime}$ end, $0.2 \mathrm{mM}$ of each dNTP, $1 \mathrm{U}$ of heat-stable polymerase (Tempase, Amplicon), $1 \times$ polymerase buffer, and $5 \mu \mathrm{l}$ of DNA. The following parameters were used for amplification: $30 \mathrm{~min}$ at $95^{\circ} \mathrm{C}$ followed by a two-step protocol consisting of 41 cycles at $95^{\circ} \mathrm{C}$ for $15 \mathrm{~s}$ and $56^{\circ} \mathrm{C}$ for $1 \mathrm{~min}$. Calculation of phytoplasma titer was by means of a cloned 16S rRNA gene standard ranging from $10^{6}$ to $10^{1}$ copies. Differences between phytoplasma virulence groups were statistically tested using analysis of variance (ANOVA) for separation of means.

Genome size estimation and macrorestriction analysis. Fulllength chromosomal DNA from five ' $\mathrm{Ca}$. P. mali' strains was prepared from N. tabacum cv. Samsun as described (17). Resolution was performed in $1 \%$ agarose in a CHEF DRIII device (Bio-Rad) with 20 to $100 \mathrm{~s}$ of switching time for $20 \mathrm{~h}$ in Tris-acetate-EDTA buffer at $6 \mathrm{~V} / \mathrm{cm}$ and $14^{\circ} \mathrm{C}$. The size of the chromosomes was

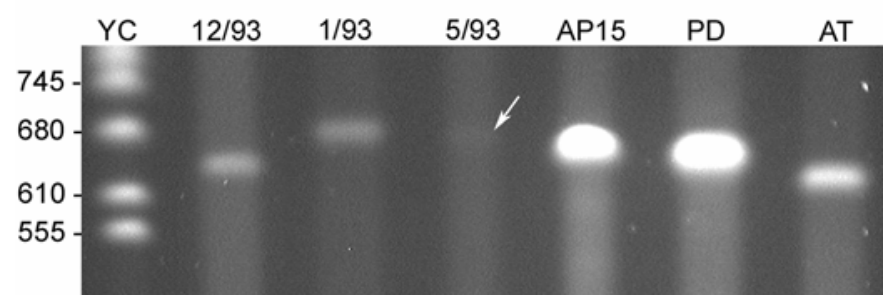

Fig. 1. Estimation of the chromosome size from 'Candidatus Phytoplasma mali' strains 12/93, 1/93, 5/93, AP15, 'Ca. P. pyri' (PD), and AT. Yeast chromosomes (YC) were used as marker. Size indicated in kilobases on the left. estimated in comparison with yeast chromosome pulsed-field gel electrophoresis markers (NEB). For RFLP analysis, DNA bands representing the chromosomes were excised and cut into small slices ( 6 by 6 by $1.5 \mathrm{~mm}$ ), equilibrated with several changes of restriction buffer, and cleaved with appropriate rare-cutting enzymes overnight. Macrorestriction fragments were resolved as described above with 1 to $15 \mathrm{~s}$ of switching time for $14 \mathrm{~h}$. Lambda ladders (NEB) were used for fragment size estimation.

\section{RESULTS}

Strain virulence. The inoculated plants were very differently affected by phytoplasma infection (Table 1). Some trees grew vigorously and did not show symptoms or rarely showed mild symptoms whereas others exhibited more or less pronounced symptoms. At the end of the observation period of 12 years, the trees could be grouped into three symptom categories and, consequently, the strains used for inoculation could be grouped into three virulence categories. In the first virulence group, referred to as avirulent and mild strains, the vigor of most trees as expressed by trunk girth was similar to that of healthy trees. Symptoms were missing or mild and, when mild, consisted of slight to moderate foliar reddening and yellowing and, rarely, enlarged stipules. Severe symptoms such as witches'-brooms and undersized fruit never occurred. Three of seven trees never developed specific symptoms and, thus, were comparable with the performance of healthy control trees.

Trees inoculated with the strains classified as moderately virulent developed symptoms nearly every year. They were most often mild but a few times included witches'-brooms and undersized fruit. In most cases, the vigor was markedly affected (Table 1). Severe strains induced severe symptoms in 9 of 12 years that resulted in drastically reduced vigor. At the end of the observation period, five of nine trees were in the final stages of decline (Table 1).

The symptoms expressed by the donor trees at the time of sampling did not always coincide with the disease development in the recipient trees (Table 1). For example, the source trees of three strains that were classified as avirulent or mild (5/93, 13/93, and 17/93) showed witches'-brooms as a severe symptom. A better correlation exists in the two other groups. In the group of moderately virulent strains, the source trees were either symptomatic or were sampled in the dormant season when foliar symptoms could not be evaluated. However, these trees did not exhibit witches'brooms and showed normal terminal growth. With one exception, the source trees of the severe strains showed reduced vigor or witches'-brooms as severe symptoms.

Phytoplasma concentrations in roots. The phytoplasma concentrations in root phloem ranged from $6.3 \times 10^{6}$ to $6 \times$ $10^{9}$ cells/g of tissue, the average over all virulence groups being $1.1 \times 10^{9}$ cells/g of tissue (Table 1 ). Only one nonsymptomatic tree $(2 / 93)$ had $1.3 \times 10^{5}$ cells/g of tissue. There were relatively small differences between the groups. The highest mean concentration was shown by the severe strains $\left(1.9 \times 10^{9}\right.$ cells/g of tissue), followed by the avirulent and mild strains $\left(1.2 \times 10^{9}\right.$ cells/g of tissue $)$ and the moderately virulent strains $\left(3.1 \times 10^{8}\right.$ cells $/ g$ of tissue). However, these differences were statistically not significant at $P=0.05$. The finding that the phytoplasma concentration in the tree with the lowest disease rating (17/93) is above the average of all trees supports the conclusion that the titer is not markedly affected by strain virulence.

Genome size of ' $\boldsymbol{C a}$. P. mali' strains. The chromosome size of five tobacco-maintained strains ranged between 640 and $680 \mathrm{~kb}$ (Fig. 1). The largest sizes are shown by low-virulence strains 1/93 and 5/93, whereas severe strain 12/93 and strains AT and AP15, which also caused severe symptoms in apple $(8,23)$, had smaller chromosomes. The phytoplasma concentrations of strains 1/93 and 5/93 in both N. occidentalis and N. tabacum cv. Samsun were 
lower than those of the other strains, as evidenced by weaker DNA bands in all preparations (Fig. 1). The chromosome size of a strain of the closely related ' $C a$. P. pyri' is in the same range as the AP phytoplasma strains.

Chromosomal RFLP patterns. Strains AT, AP15, 1/93, 5/93, and 12/93 that were maintained in tobacco were used for RFLP analysis of full-length chromosomes employing endonucleases ApaI, BamHI, BssHII, MluI, and SmaI (Fig. 2). From strains 1/93, $5 / 93$, and $12 / 93$, only low amounts of DNA were available, so that weak bands often were obtained. For this reason, the data from these strains are depicted in a diagrammatic presentation.

The profiles of the five strains reveal that, with each enzyme, each strain showed a distinct profile that was different from the profiles of other strains (Fig. 2). Only a few bands were shared, which may reflect homologous fragments. The number of fragments generated by a given enzyme differed between the strains, except for digestion with BssHII that always resulted in two fragments which were different in size. The remaining restriction enzymes cut more frequently, in particular BamHI that produced the most fragments in all strains. However, the data obtained with this enzyme are shown only for strains AT and AP15 because the other strains showed very tight banding patterns or weak fluorescence in the agarose gel.

Genomic differences in the five strains maintained in periwinkle and tobacco AT, AP15, 1/93, 5/93, and 12/93 also were examined by Southern blot hybridization of restricted phytoplasma-enriched DNA with the mixture of PCR probes 3-1/3-2, $82 / 83$, and 200/201 derived from the sequence of strain AT (Table 2 ). In this comparison, there was more similarity between the strains than in the comparison of macrorestriction fragments (Fig. 3). Following digestion with EcoRI, the five strains could be assigned to two groups according to their different profiles. Also, digestion with EcoRV and XbaI resulted in several bands of the same size. However, in this case, all strains showed different overall patterns with each enzyme (Fig. 3).

Differential amplification of ' $\boldsymbol{C}$ a. P. mali' strain DNA. Seven primer pairs were selected to examine the presence of homologous DNA fragments in the greenhouse-maintained strains (Fig.
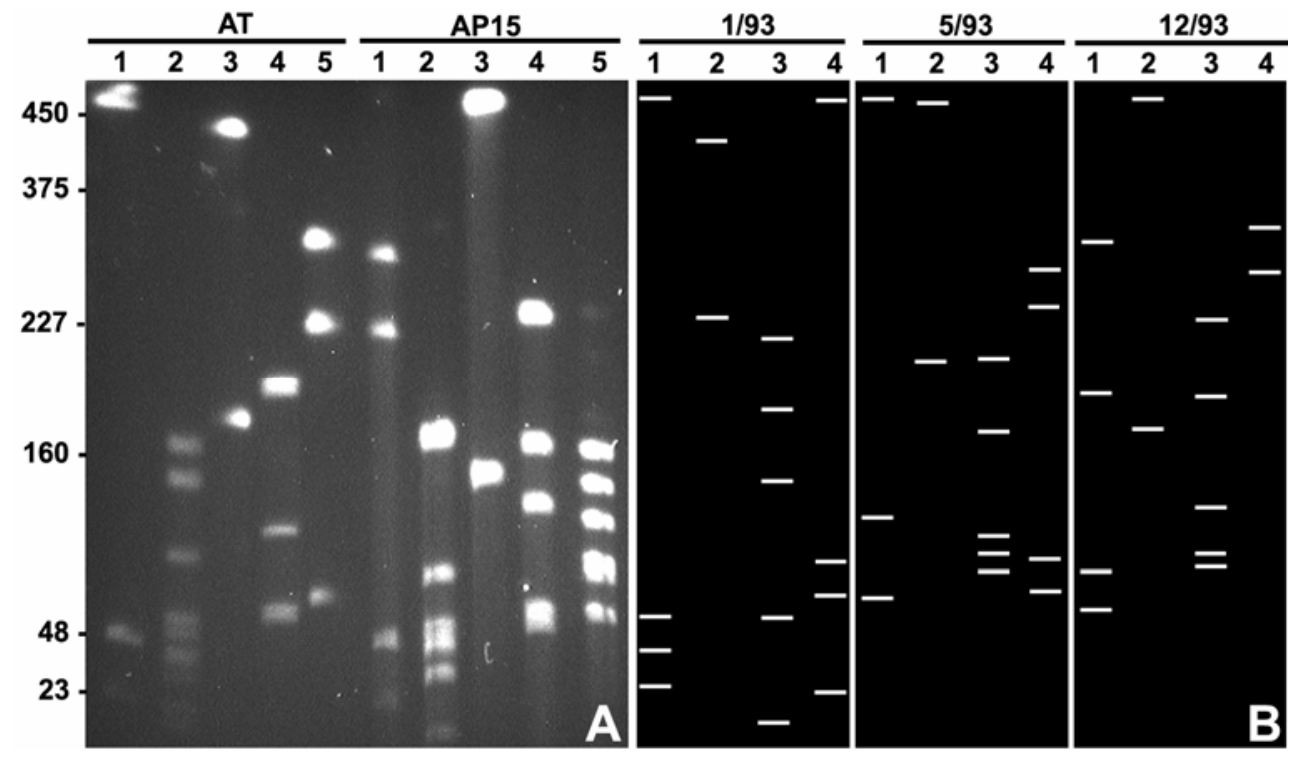

Fig. 2. Macrorestriction fragment patterns of full-size chromosomes from 'Candidatus Phytoplasma mali' strains. A, Ethidium-bromide-stained gel of strains AT and AP15. B, Diagrammatic presentation of macro fragments from strains 1/93, 5/93, and 12/93 (1, ApaI; 2, BamHI; 3, Bss HI; 4, MluI; 5, SmaI). Position of the size marker is given in kilobases on the left.

TABLE 2. Sequences of polymerase chain reaction primers and Taqman probe and their priming sites

\begin{tabular}{|c|c|c|}
\hline Primer designation & Sequence $\left(5^{\prime}-3^{\prime}\right)$ & Priming site \\
\hline 3-1 & TTCATGATAAGCAACCATAC & ATP-dependant $\mathrm{Zn}$ protease $h l f \mathrm{~B}$ \\
\hline $3-2$ & TTCTAGCTATTCATCGTG & ATP-dependant $\mathrm{Zn}$ protease $h l f \mathrm{~B}$ \\
\hline $4-1$ & ATTCAATATGCCTTTGGCAC & Oligopeptide $\mathrm{ABC}$ transporter $о p p \mathrm{~A}$ \\
\hline 27 & GATAATGAATTAGCTACTTCACCT & DNA pol. III $\alpha$ subunit $p o l C$ \\
\hline 33 & ACGACGTTAAAATCGTTGTTTT & Replicative DNA helicase $d n a \mathrm{~B}$ \\
\hline 34 & TCAAAATGAATTCAGGTATTGCT & Replicative DNA helicase $d n a \mathrm{~B}$ \\
\hline 41 & CGTTTAATTTTGCCAGTTTCG & Hypothetical protein gene \\
\hline 83 & GTGGATTAATTAGTCCAAAAG & Noncoding region \\
\hline 100 & CCGATAATGCATTATAATGC & Dimethyladenosine transferase $k s g \mathrm{~A}$ \\
\hline 103 & GGTTTTGTTGCTCCGGTTAG & Hypothetical protein gene \\
\hline 200 & GCTАССССТАТТССТААААСС & ATP-dependant DNA helicase $r e c \mathrm{G}$ \\
\hline 201 & GCTCCTGCATCTAATAAAATACG & Phospholipid biosynthesis pls $\mathrm{X}$ \\
\hline 216 & GCCAGATGTTCCTAGCAAAG & Hypothetical protein gene \\
\hline 220 & GCGGCCGCTTTTTTGCTTAAATATTTG & ABC-type $\mathrm{Mn} / \mathrm{Zn}$ transporter $z n u \mathrm{~A}$ \\
\hline
\end{tabular}


4). At an annealing temperature of 52 or $55^{\circ} \mathrm{C}$, all primer combinations gave strong PCR bands with the homologous strain AT, whereas only five pairs amplified the target DNA from strain AP15, four pairs from strain 1/93, three pairs from strain 5/93, and two pairs from strains $12 / 93$ and AT-2. However, after reducing the annealing temperature to $\leq 50^{\circ} \mathrm{C}$, amplification products were obtained with all primer pairs from all strains. This indicates the presence of a few mismatches in some strains. The sizes of the amplified PCR fragments were identical to those of the homologous strain AT. An additional primer pair (100/103) was designed to amplify a product flanking one of the SmaI restriction sites. These primers mediated amplification of a $2.1-\mathrm{kb}$ product from all strains; however, the $S m a$ I restriction site was only present in strains AT, AP15, and 5/93 (data not shown). Restriction of the amplimers shown in Figure 4 with the frequently cutting enzymes AluI, HinfI, and TaqI resulted in identical profiles for each group of products (data not shown).

AP phytoplasma DNA from the strains included in the virulence trial was subjected to amplification with five primer pairs

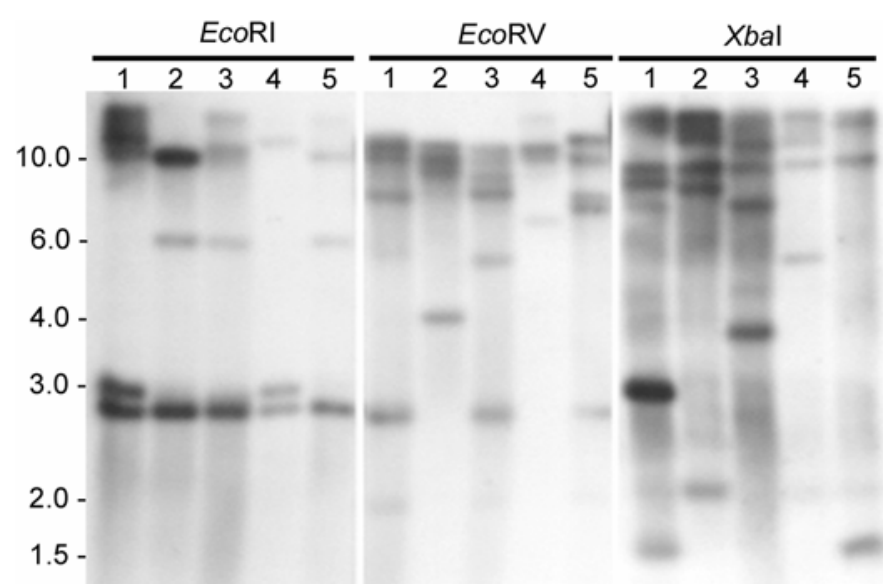

Fig. 3. Southern blot hybridization of EcoRI-, EcoRV-, and XbaI-restricted DNA from 'Candidatus Phytoplasma mali' strains with a mixture of polymerase chain reaction probes 3-1/3-2, 82/83, and 200/201. 1, AT; 2, AP15; $3,1 / 93 ; 4,5 / 93 ; 5,12 / 93$. Position of the $1-\mathrm{kb}$ marker is given in kilobases on the left.

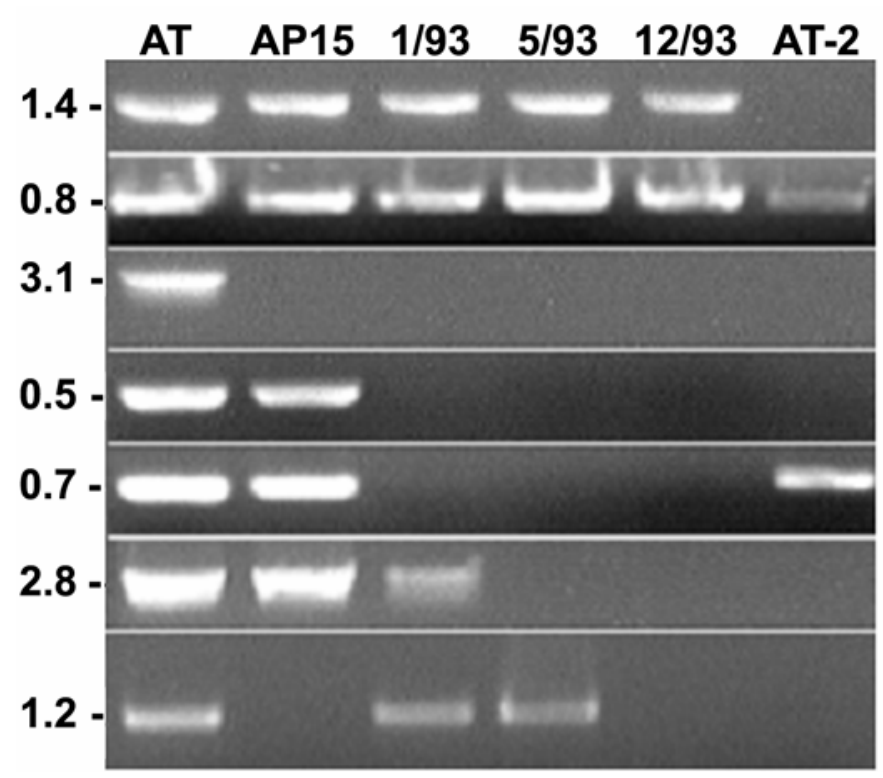

Fig. 4. Differential polymerase chain reaction PCR amplification of six apple proliferation (AP) phytoplasma strains with primer combinations 3-1/4-1, $82 / 83,216 / 220,26 / 27,33 / 34,41 / 42$, and f318A/r318B (from top to bottom). Size of the amplimers is given in kilobases on the left.
(Table 3). Primers f318A/r318B enabled differentiation of subtypes AT (+) and AP (-). These subtypes are equally represented across the strains examined. The pattern of subtype AT-2 (Fig. 4) is shown by strain 21/93. Altogether, a total of 13 different profiles was obtained. It is interesting to note that the patterns from strains 1/93 and 5/93 were different when DNA from field trees and, after transmission, from tobacco was amplified (Table 3; Fig. 4). This may indicate the presence of more than one AP strain in these trees.

\section{DISCUSSION}

The results of this graft inoculation study indicate that strains of ' $\mathrm{Ca}$. P. mali' differ greatly in virulence. The range of aggressiveness extended from being virtually avirulent to affecting trees so severely that they were in the final stage of decline at the end of the observation period. A similar wide range of virulence was observed in previous work in which trees on different Prunus genotypes were inoculated with various strains of ' $\mathrm{Ca}$. P. prunorum'. Because trees on certain Prunus genotypes were more susceptible than Malus $\times$ domestica genotypes such as M 11, the response was even more drastic because up to $100 \%$ of the trees died, whereas trees on others rootstocks were little or not affected (14). Avirulence is very common in the alder yellows phytoplasma because, at least in southwestern Germany, most alders are infected but only a minority are symptomatic $(6,18)$. Differences in strain virulence also were observed in ' $\mathrm{Ca}$. P. fraxini' because growth suppression and foliar greenness depended much on the strain (34).

Although severity of symptoms which developed in inoculated trees was, in most cases, similar to the symptoms shown by the donor trees, there were several exceptions. One tree (6/93) inoculated with a scion from a nonsymptomatic tree developed severe symptoms whereas three trees developed mild or no symptoms following inoculation with scions from trees showing witches'-

TABLE 3. Differential polymerase chain reaction (PCR) amplification of DNA from the 'Candidatus Phytoplasma mali' strains examined

\begin{tabular}{|c|c|c|c|c|c|}
\hline \multirow[b]{2}{*}{ Strain no. ${ }^{a}$} & \multicolumn{5}{|c|}{ PCR amplification with primers ${ }^{b}$} \\
\hline & $\mathrm{f} 318 \mathrm{~A} / \mathrm{r} 318 \mathrm{~B}$ & $3-1 / 4-1$ & $26 / 27$ & $33 / 34$ & $82 / 83$ \\
\hline \multicolumn{6}{|l|}{ Mild } \\
\hline $17 / 93$ & + & + & + & + & + \\
\hline $2 / 93$ & - & - & - & + & - \\
\hline $5 / 93$ & + & - & + & + & + \\
\hline $1 / 93$ & + & + & + & + & + \\
\hline $15 / 93$ & - & + & - & - & + \\
\hline $13 / 93$ & + & + & + & + & + \\
\hline $4 / 93$ & + & - & + & + & + \\
\hline \multicolumn{6}{|l|}{ Moderate } \\
\hline $24 / 93$ & - & - & - & - & + \\
\hline $22 / 93$ & - & - & + & - & + \\
\hline $16 / 93$ & + & + & + & + & + \\
\hline $7 / 93$ & + & - & + & + & - \\
\hline $21 / 93$ & - & - & - & + & + \\
\hline $23 / 93$ & + & - & + & - & + \\
\hline $10 / 93$ & + & + & + & + & + \\
\hline $25 / 93$ & - & + & + & - & + \\
\hline \multicolumn{6}{|l|}{ Severe } \\
\hline $14 / 93$ & + & + & + & + & + \\
\hline $20 / 93$ & - & + & - & - & + \\
\hline $6 / 93$ & - & - & + & + & + \\
\hline $9 / 93$ & + & + & + & + & + \\
\hline $12 / 93$ & - & + & - & - & + \\
\hline $3 / 93$ & + & + & + & + & + \\
\hline $18 / 93$ & - & + & - & - & + \\
\hline $19 / 93$ & - & - & - & - & + \\
\hline $8 / 93$ & - & + & + & + & + \\
\hline
\end{tabular}

${ }^{\mathrm{a}}$ Mild $=$ avirulent and mild, Moderate $=$ moderately virulent, and Severe $=$ severe strains.

b PCR product indicated as + or $-=$ present or missing, respectively. 
brooms. There may be several reasons for this phenomenon. First, disease history of most source trees was unknown and most trees were older than 10 years. Witches'-brooms are formed only from vigorously growing trees and often only at the beginning of disease appearance. After the acute phase, trees may recover and often remain nonsymptomatic over long periods, especially when older (30). The existence of a severe strain in a nonsymptomatic older tree can be explained in this way.

More difficult to understand is when inoculum from trees showing witches'-broom symptoms caused mild or no symptoms in the recipient trees. One possibility is that there are pathovars in ' $C a$. P. mali' that affect certain genotypes of a given host species more than others. Such host specificity is common in many plant pathogens but so far unknown in phytoplasmas. Although one of the three strains in question was from a commercial cultivar, the fact that the two other donor trees were an unidentified crab apple and a wild seedling from either Malus $\times$ domestica or $M$. sylvestris may support the idea that such a specificity exists. Another more likely explanation is that there were mixed phytoplasma populations in the donor trees, of which an avirulent strain took over in the inoculated tree. Mixed infections appear to be quite common $(19,21)$. According to these authors and Lee et al. (20), there may be a primary and secondary phytoplasma in a dually infected plant whereby the secondary agent may be present at very low titer. After transmission to another host that is more suitable for the secondary phytoplasma, this may build up to become the primary pathogen. Sinclair and Griffith $(33,34)$ reported that, when either mild or severe strains of ' $\mathrm{Ca}$. P. fraxini' were inoculated 11 weeks before the other into the same plant, only the initial strain could be detected after a further 12 weeks of incubation. Their explanation is that the initial strain or its effect on the host may have interfered with multiplication or longdistance movement of the second strain. It is conceivable that the same may happen when the titer of one strain is higher than the other. The finding that, with strains $1 / 93$ and 5/93, differential PCR resulted in different patterns in apple and tobacco supports the idea that different AP phytoplasma strains were present in apple.

The phytoplasma titer determined in this work is in the same range as previously determined for rootstock M 11 using a competitive PCR procedure (5). The concentration reported for pear and stone fruit infected with the close ' $\mathrm{Ca}$. P. mali' relatives ' $\mathrm{Ca}$. P. pyri' and ' $C a$. P. prunorum' (36) was $\approx 100,000$ times lower than in M 11. In this case, the differences are at least partially due to the kind of tissue examined. Torres et al. (36) extracted DNA from leaf midribs whereas we used root phloem that is known to be a much better phytoplasma DNA source (29). Phytoplasma concentration in the three virulence categories did not differ significantly. This indicates that avirulent and mild strains have the same fitness as severe strains for multiplying and spreading in apple. However, avirulent and mild strains obviously lack the genetic setup to markedly affect the host.

The results of all attempts to genetically characterize the AP phytoplasma strains examined indicate that there is a considerable heterogeneity in ' $\mathrm{Ca}$. P. mali'. The apparent size of the chromosomes differs in all strains examined and ranges between 640 and $680 \mathrm{~kb}$ compared with yeast chromosomes. However, as revealed in the genome sequencing project of strain AT (M. Kube, B. Schneider, and E. Seemüller, unpublished data), the actual size of the strain AT chromosome is $\approx 602 \mathrm{~kb}$ instead of $640 \mathrm{~kb}$ compared with yeast chromosomes. Thus, the chromosome size of the other strains is likely to be smaller, too. The altered mobility relative to yeast chromosomes probably is due to the extremely low $\mathrm{G}+\mathrm{C}$ content (15) and physical structures of phytoplasma chromosomes.

The differences in chromosome size in ' $\mathrm{Ca}$. P. mali' strains is exceeded by strains of the aster yellows phytoplasma group represented by ' $C a$. P. asteris' $(3,22,24)$. In our work, the largest chro- mosomes have been determined for the two avirulent or mild strains $1 / 93$ and 5/93, whereas the virulent strains AT, AP15, and $12 / 93$ have smaller chromosomes. In other work, it has been shown that a derivative line of the onion yellows phytoplasma causes milder symptoms and has a smaller chromosome than the wild type. According to the authors, the reduced virulence of the derivative line may be due to the loss of genes involved in pathogenicity (25). Such a correlation obviously does not exist for ' $\mathrm{Ca}$. P. mali'. It is conceivable that differences in pathological traits such as virulence may result from reorganization of the genome such as duplication of genes and presence of insertion elements rather than from gain or loss of accessory chromosomal material. Multiple occurrences of paralogous genes and insertion elements are known from the two aster yellows phytoplasmas from which the complete genome sequence is available $(3,24)$.

Also, our PCR- and RFLP-based approaches did not result in the identification of markers linked to virulence. However, they show the genetic diversity in ' $\mathrm{Ca}$. P. mali' and can be the basis for further studies. Considering the small, densely coding phytoplasma chromosomes, it appears feasible that further comparisons of DNA fragments from avirulent and severe strains will lead to the identification of sequences present in one type and absent in the other. One possibility to reach this goal is a more detailed analysis of the differences in macrorestriction patterns. Another promising attempt to find relevant sequences has been made by using a set of strain AT-derived primers for amplification of DNA from five other AP phytoplasma strains. Although we succeeded in a differential DNA amplification from these strains, the missing products were obtained by lowering the annealing temperature. Hence, only a few mismatches appear to be responsible for the failure. Nevertheless, positive results may be obtained with other primer combinations that are available from strain AT chromosome sequence. However, the most promising method to find differences between virulent and avirulent strains would be the sequence comparison of two entire chromosomes of such strains. Knowledge of genes mediating pathogenicity and virulence is urgently needed to study the largely unknown phytoplasma pathology and to screen existing genotypes and breeding progenies for phytoplasma resistance.

\section{ACKNOWLEDGMENTS}

The research was supported as part of the SMAP projects by grants from the Provincia Autonoma di Trento and the Istituto Agrario di S. Michele all' Adige (Italy). We thank S. Sule for his cooperation in the quantitative PCR work, F. Hergenhahn for transmission of ' $\mathrm{Ca}$. P. mali' strains to periwinkle and tobacco, and Constanze Berwarth for technical assistance.

\section{LITERATURE CITED}

1. Ahrens, U., and Seemüller, E. 1992. Detection of DNA of plant pathogenic mycoplasmalike organisms by a polymerase chain reaction that amplifies a sequence of the 16S rRNA gene. Phytopathology 82:828832 .

2. Ahrens, U., and Seemüller, E. 1994. Detection of mycoplasmalike organisms in declining oaks by polymerase chain reaction. Eur. J. For. Pathol. 24:55-63.

3. Bai, X. D., Zhang, J. H., Ewing, A., Miller, S. A., Radek, A. J., Shevchenko, D. V., Tsukerman, K., Walunas, T., Lapidus, A., Campbell, J. W., and Hogenhout, S. A. 2006: Living with genome instability: the adaptation of phytoplasmas to diverse environments of their insect and plant hosts. J. Bacteriol. 188:3682-3696.

4. Berg, M., Davies, D. L., Clark, M. F., Vetten, H. J., Maier, G., Marcone, C., and Seemüller, E. 1999. Isolation of the gene encoding an immunodominant membrane protein of the apple proliferation phytoplasma, and expression and characterization of the gene product. Microbiology 145:1937-1943.

5. Berges, R., Rott, M., and Seemüller, E. 2000. Range of phytoplasma concentrations in various plant hosts as determined by competitive polymerase chain reaction. Phytopathology 90:1145-1152. 
6. Berges, R., and Seemüller, E. 2002. Impact of phytoplasma infection of common alder (Alnus glutinosa) depends on strain virulence. For. Pathol. 32:357-363.

7. Carraro, L., Ermacora, P., Loi, N., and Osler, R. 2004. The recovery phenomenon in apple proliferation-infected apple trees. J. Plant Pathol. 86:141-146.

8. Carraro, L., Osler, R., Refatti, E., and Poggi Pollini, C. 1988. Transmission of the possible agent of apple proliferation to Vinca rosea by dodder. Riv. Patol. Veg. Ser. IV 24:43-52.

9. Doyle, J. J., and Doyle, J. L. 1990. Isolation of plant DNA from fresh tissue. Focus (BRL) 12:13-15.

10. Firrao, G., Smart, C. D., and Kirkpatrick, B. C. 1996. Physical map of the western X-disease phytoplasma chromosome. J. Bacteriol. 178:39853988.

11. Frisinghelli, C., Delaiti, L., Grando, M. S., Forti, D., and Vindimian, M. E. 2000. Cacopsylla costalis (Flor 1861), as a vector of apple proliferation in Trentino. J. Phytopathol. 148:425-431.

12. Jarausch, W., Saillard, C., Helliot, B., Garnier, M., and Dosba, F. 2000. Genetic variability of apple proliferation phytoplasmas as determined by PCR-RFLP and sequencing of a non-ribosomal fragment. Mol. Cell. Probes 14:17-24.

13. Kison, H., Schneider, B., and Seemüller, E. 1994. Restriction fragment length polymorphism within the apple proliferation mycoplasmalike organism. J. Phytopathol. 141:395-401.

14. Kison, H., and Seemüller, E. 2001. Differences in strain virulence of the European stone fruit yellows phytoplasma and susceptibility of stone fruit trees on various rootstocks to this pathogen. J. Phytopathol. 149:533-541.

15. Kollar, A., and Seemüller, E. 1989. Base composition of the DNA of mycoplasmalike organisms associated with various plant diseases. J. Phytopathol. 127:177-186.

16. Kunze, L. 1976. The effect of different strains of apple proliferation on the growth and crop of infected trees. Mitt. Biol. Bundesanst. LandForstwirtsch. Berlin-Dahlem 170:107-115

17. Lauer, U., and Seemüller, E. 2000. Physical map of the chromosome of the apple proliferation phytoplasma. J. Bacteriol. 182:1415-1418.

18. Lederer, W., and Seemüller, E. 1991. Occurrence of mycoplasma-like organisms in diseased and non-symptomatic alder trees (Alnus spp.). Eur. J. For. Pathol. 21:90-96.

19. Lee, I.-M., Davis, R. E., and Gundersen-Rindal, D. E. 2000. Phytoplasma: Phytopathogenic mollicutes. Annu. Rev. Microbiol. 54:221-255.

20. Lee, I.-M., Gundersen, D. E., Hammond, R. W., and Davis, R. E. 1994. Use of mycoplasmalike organism (MLO) group-specific oligonucleotide primers for nested-PCR assays to detect mixed-MLO infections in a single host plant. Phytopathology 84:559-566.

21. Lee, I.-M., Martini, M., Bottner, K. D., Dane, R. A., Black, M. C., and Troxclair, N. 2003. Ecological implications from a molecular analysis of phytoplasmas involved in an aster yellows epidemic in various crops in Texas. Phytopathology 93:1368-1377.

22. Marcone, C., Neimark, H., Ragozzino, A., Lauer, U., and Seemüller, E. 1999. Chromosome sizes of phytoplasmas composing major phylogenetic groups and subgroups. Phytopathology 89:805-810.

23. Marwitz, R., Petzold, H., and Özel, M. 1974. Untersuchungen zur
Übertragbarkeit des möglichen Erregers der Triebsucht des Apfels auf einen krautigen Wirt. Phytopathol. Z. 81:85-91.

24. Oshima, K., Kakizawa, S., Nishigawa, H., Jung, H. Y., Wei, W., Suzuki, S., Arashida, R., Nakata, D., Miyata, S., Ugaki, M., and Namba, S. 2004. Reductive evolution suggested from the complete genome sequence of a plant-pathogenic phytoplasma. Nat. Genet. 36:27-29.

25. Oshima, K., Shiomi, T., Kuboyama, T., Sawayanagi, T., Nishigawa, H., Kakizawa, S., Miyata, S., Ugaki, M., and Namba, S. 2001. Isolation and characterization of derivative lines of the onion yellows phytoplasma that do not cause stunting or phloem hyperplasia. Phytopathology 91:10241029.

26. Sambrook, J., Fritsch, E. F., and Maniatis, T. 1989. Molecular Cloning: A Laboratory Manual. Cold Spring Harbor Laboratory Press, Cold Spring Harbor, NY.

27. Schaper, U., and Seemüller, E. 1982. Condition of the phloem and the persistence of mycoplasmalike organisms associated with apple proliferation and pear decline. Phytopathology 72:736-742.

28. Seemüller, E., Kison, H., and Lorenz, K.-H. 1998. On the geographic distribution and prevalence of the apple proliferation phytoplasma in lowintensity orchards in Germany. Z. Pflanzenkrankh. Pflanzenschutz 105:404-410.

29. Seemüller, E., Kison, H., Lorenz, K.-H., Schneider, B., Marcone, C., Smart, C. D., and Kirkpatrick, B. C. 1998. Detection and identification of fruit tree phytoplasmas by PCR amplification of ribosomal and nonribosomal DNA. Pages 55-66 in: COST 823: New Technologies to Improve Phytodiagnosis. C. Manceau, ed. European Community, Luxembourg.

30. Seemüller, E., Kunze, L., and Schaper, U., 1984: Colonization behavior of MLO, and symptom expression of proliferation-diseased apple trees and decline-diseased pear trees over a period of several years. Z. Pflanzenkrankh. Pflanzenschutz 91:525-532.

31. Seemüller, E., Schaper, U., and Zimbelmann, F. 1984. Seasonal variation in the colonization patterns of mycoplasmalike organisms associated with apple proliferation and pear decline. Z. Pflanzenkrankh. Pflanzenschutz 91:371-382.

32. Seemüller, E., and Schneider, B. 2004. 'Candidatus Phytoplasma mali', 'Candidatus Phytoplasma pyri' and 'Candidatus Phytoplasma prunorum', the causal agents of apple proliferation, pear decline and European stone fruit yellows, respectively. Int. J. Syst. Evol. Microbiol. 54:1217-1226.

33. Sinclair, W. A., Gleason, M. L., Griffiths, H. M., Iles, J. K., Zriba, N., Charlson, D. V., and Batzer, J. C. 2000. Responses of 11 Fraxinus cultivars to ash yellows phytoplasma strains of differing aggressiveness. Plant Dis. 84:725-730.

34. Sinclair, W. A., and Griffiths, H. M. 2000. Variation in aggressiveness of ash yellows phytoplasmas. Plant Dis. 84:282-288.

35. Tedeschi, R., and Alma, A. 2004. Transmission of apple proliferation phytoplasma by Cacopsylla melanoneura (Homoptera:Psyllidae). J. Econ. Entomol. 97:8-13.

36. Torres, E., Bertolini, E., Cambra, M., Monton, C., and Martin, M. P. 2005. Real-time PCR for simultaneous and quantitative detection of quarantine phytoplasmas from apple proliferation (16SrX) group. Mol. Cell. Probes $19: 334-340$ 